\title{
THE BODY AS AN ARCHIVE
}

\section{O corpo como um arquivo}

\author{
Ruan Nunes Silva ${ }^{1}$ \\ ${ }^{1}$ Universidade Estadual do Piauí. Parnaíba, PI, Brasil. \\ E-mail: ruan.nunes@hotmail.com
}

\section{RESUMO}

Este trabalho busca oferecer uma compreensão do corpo como um arquivo ao analisar poemas escritos por Danez Smith, poeta e performer queer não-binárie. Visto como um campo conflitante por disputas de poder e controle, o arquivo pode ser lido de diversas formas e este trabalho se aproxima dele para teorizar o que práticas arquivistas queer podem sinalizar quando elementos como gênero, sexualidade e desejo são interrogadas nos poemas de Smith. Considerando as contribuições teóricas de Celia Pedrosa et al. (2018), Julietta Singh (2018) David Lapoujade (2017), Ann Cvetkovich (2003) e outros, pode-se concluir que os poemas de Smith exibem uma complexa negociação entre sentimentos e o mundo, permitindo que novos sentidos irrompam do arquivo.

Palavras-chave: Danez Smith; arquivo; corpo; estudos queer.

EDITOR-CHEFE:

Gerson Roberto Neumann

EDITOR EXECUTIVO:

Regina Zilberman

SUBMETIDO: 30.04 .2021

ACEITO: 15.06 .2021

\section{ABSTRACT}

This paper aims to offer an understanding of the body as an archive while analysing poems written by queer and non-binary poet and performer Danez Smith. Seen as a conflicting field for power and control disputes, the archive can be read in different ways and this paper approaches it in order to theorise what a queer archival practice may signal when elements such as gender, sexuality and desire are interrogated in Smith's poems. Taking into consideration theoretical contributions from Celia Pedrosa et al. (2018), Julietta Singh (2018), David Lapoujade (2017), Ann Cvetkovich (2003) and others, it is concluded that Smith's poems display a complex negotiation of feeling and the world, allowing new meanings to erupt from the archive.

KEYworDs: Danez Smith; archive; body; queer studies.

\section{COMO CITAR:}

SILVA, Ruan Nunes. The body as an archive. Revista Brasileira de Literatura Comparada, v. 23 , n. 44 , p. $78-89$, set.dez., 2021. doi: https:// doi.org/10.1590/2596$304 \times 20212344$ rns 


\section{WHAT ARCHIVES CAN DO, WHAT BODIES CAN FEEL}

In Indicionário do Contemporâneo ${ }^{1}$, Celia Pedrosa et al. (2018) argue that, from a Benjaminian perspective, the archive is not defined as much by what it holds, but by the relations subjects establish with objects, images and words. The authors and organisers go on to state that reflections upon an archive should not attempt to draw defining lines as to what is part of the public domain and what is part of the private realm, or even what is part of cultural and collective memory and what is part of individual and personal recollection. The aim behind such avoidances is one that requires not only a reflection in which these lines are blurred, but also one in which the archive works in close negotiation with fields seen either as public or as private such as sexuality, gender, class and race.

Seen as a conflicting field for power and control disputes, the archive cannot be understood as the past itself because it is the very practice of going through - or even controlling - the archive which allows one to construct the past. In other words, what is understood as public or private is negotiated through representations of the archive which in turn offers readings oriented by those who approach it. Such archival readings, guided by different modes of reading, may or may not obscure some parts of the very archive it comes from. This is why Pedrosa et al. (2018) argue that these modes of reading as well as of archiving are what may establish meanings: an authoritarian reader is more likely to look for fixed meanings whereas a nomad reader may appreciate the lack of definitions and look for new possibilities. Thus, to think of the archive as traces which construct other experiences and not as documents which fix those is to breathe life into it, to bring back, even if only as a spectral presence, something which haunted the archive and was hitherto unmediated.

With regard to spectrality as part of the archive, we may evoke Carla Freccero's words concerning how "the past is in the present in the form of haunting." (2007, p. 194) Although she is not fully interested in archival matters, Freccero develops the idea of queer spectrality as part of historiography with a view to understanding how our contemporary attitudes towards the past may reconfigure our futures. Such reading unmistakably leads us to the archive and the ways in which it is read: if the past is in the present as a haunting, what does it mean to assess the present as a problem? Also, what does it mean to approach the archive and understand that we cannot come to terms with what it offers us all the ugly and backward feelings (NGAI, 2005; LOVE, 2009) we do not want to partake anymore? What does it mean to queer the archive in an attempt to understand this spectrality?

What happens when we approach the archive is that it becomes increasingly challenging to make amends with a past with which we are not either familiar or acquainted. Images, narratives, stories - these are elements the archive offers us and which we may choose to overlook in favour of more positive or bright-looking models. This affirmative turn, one oriented by happiness and positive narratives, is criticised by several theorists such as Sara Ahmed (2010) and Heather Love (2009) because both understand that ignoring the past and the difficult objects it offers is not going to help the present or even the future. Thus, it is a wiser and more fruitful move to approach the hauntings from our archives not with the aim of making peace, but with an eye to making sure they are integral parts of

1 It is worth highlighting that this is a transdisciplinary and collectively organized "dictionary" of literary terms and concepts which is yet to be translated into other languages. Organized by four university professors based in Brazil, the book was written collectively by 14 authors, giving each term a consistent and wide-ranging theoretical framework. 
queer historiography. This way we refuse authoritarian positions as readers, making room for a nomad position or even a reparative one (SEDGWICK, 2003) in which new meanings (even those which might frustrate us) are not necessarily bad because we may make sense out of these negative feelings.

I have argued so far that the archive holds meanings with which we may not be familiar, either for our lack of access to the archive (who made it inaccessible in the first place?) or for our inability to read it in the position of reparative/nomad readers (what should we do with all these unhappy queer endings?). Becoming acquainted with archives may help LGTBQ+ subjects understand more of their own history instead of accepting heteronormative models which perpetuate exclusion. The archive, then, is definitely a contested site in which decisions on who can be seen and who cannot are urgent and demand attention. Archives can, thus, empower us to question the ways in which LGBTQ+ have been allured not only by neoliberal discourses, but also by models which offer us safety at the expense of the lives of other non-normative subjects. In short, what archives can do is to make some existences become (more) real, especially lesser existences as discussed by David Lapoujade (2017).

Inspired by philosopher Etienne Souriau's theories on modes of existence, David Lapoujade (2017) points out that only because some existences are not real does not necessarily mean they do not exist. In simpler terms, Lapoujade argues that two terms which are often mixed up and used interchangeably are reality and existence: people are real and they are here in time and space, but so are imaginary things, often deemed to be unreal as if lacking characteristics featured in existent beings. What the French philosopher attempts to do is to highlight that some existences, even imaginary ones, ones not fully real yet, exist and, for this very reason, they need the conditions for their flourishing.

Lapoujade states that to become real one needs to become legitimised. "We know", Lapoujade (2017, p. 91, my translation) says, "that the best way to cease an existence is to pretend that it has no reality." Denying an existence is different from doubting an existence: while the former recognises an existence so as to ignore it, the latter clearly ignores the existence. It is the doubt that, in Lapoujade's view, which is an issue: not only does it not prevent things from existing (because they will exist nonetheless), but it also fails at acknowledging the potentiality of that existence. Deprived of its potential to be real, this existence still exists and resists, but mostly in a fragile and vulnerable position; hence their condition of lesser existences. This is what Lapoujade describes as a challenge: how can we make these "lesser existences" more real? How can we ensure they are not condemned to be only spectral presences in our lives?

These questions lead us back to the matter of the archive: these lesser existences are here and there, yet they have been denied their right to be real. Put simply, my understanding is that some LGBTQ+ existences may be considered lesser ones for their potentiality which is yet to be fulfilled. It is clear that the existence of LGBTQ+ subjects cannot be denied because they are here, but their right to be real is seriously doubted when they are made to disappear from archives. This is the challenge we are faced nowadays: to think the archive through its traces, specters, and ruins. (PEDROSA et al., 2018) To queer the archive is to put into practice what Gayatri Gopinath $(2018$, p. 11) describes as "[...] archival practices that excavate and memorialize the minor histories (personal, familial, collective, regional) that stand outside of the official nation-centered narratives."

Reading the archive for new meanings may help us as nomad/reparative readers to make some existences more real. When it comes to the existence of LGBTQ+ subjects, it is arguable that bodily 
experiences have been at the heart of the matter, for their own decision to exist has been a refusal of norms and conventions. I am thinking here of several examples in which bodies mattered and made a difference: Stephen Gordon in The Well of Loneliness, Beebo Brinker in Ann Bannon's book series, or even Jess Golberg in Leslie Feinberg's Stone Butch Blues. All these novels have become canonical works in the LGBTQ+ world and they offer characters who not only challenge norms by acting against them, but they also defy the world with their very own bodily existence. As Judith Butler (1993) argues, bodies matter. What does it mean, then, to think of the body as an archive, as a site in which narratives are also at stake?

I argue that bodily experiences are not to be considered as only a side of the now outdated perspective of mind/body. Rather, in tune with queer and affect theorists, I understand bodily experiences as affectively saturated, especially because bodies cannot exist without our affective expressions. What we feel can also inform the ways in which we read the world. Yet, affects do not circulate randomly and they do adhere more to some bodies than others socially as Clare Hemmings (2005) states. This is why a discussion of the body as an archive while reading Danez Smith's poems is going to rely on the sociality of bodies as a condition for affects to "stick" more to some bodies instead of others.

For the last thirty or more years feminist and queer studies have approached the body as a site of disputes in which race, class, gender, sexuality and other features are essential categories of analysis. Refusing a framework in which all bodies are understood the same way, several theorists and critics from both fields have managed to underline how experiences cannot be understood universally and how those previously mentioned categories organise these experiences. Essentialist views of the body have been questioned and debunked in favour of others which privilege intersectional investigations of how subjects are affected. Yet, as Jennifer C. Nash (2019, p. 100) discusses in Black Feminism Reimagined, intersectionality is yet to attune to "questions of movement, sensation, and affect" due to its "imagined attachment to the category of identity." Thus, intersectional analyses are still laden with identity discussions which might seek to establish essentialist and fixed ideas of what bodies are meant to mean in specific contexts. This is not to say, however, as Nash also recalls, that intersectional investigations are to be left behind or overlooked. The aim is to go beyond these established understandings of bodies as fixed beings because of how categories intersect.

Understanding that categories such as race, class, gender and sexuality inform a body is not the same as applying them to create stable meanings of bodies. Intersectional analyses which centre themselves on the image of the black woman may end up perpetuating the very stereotypes they are working against. As Nash highlights, what she advocates is:

[...] a conception of intersectionality expansive, broad and deterritorialized enough to move with figures beyond "black woman" [and which] surrenders its exclusive investment in black woman and emphasizes the analytic's capacity to speak to "women of colour" broadly." (NASH, 2019, p. 104)

I strongly believe that Nash's conception of intersectionality offers an interesting step towards more fruitful investigations, especially considering her adherence to affects as a site of thinking bodies. By employing intersectionality as an analytic which surrenders its own foundational narratives and its focus on black women, Nash calls for investigations which make room for new understandings of 
theories. This is the intersection in which the body as an archive is located. What, then, can intersectional and affective readings do to help us read the body?

In No Archive Will Restore You Julietta Singh deviates from the question of what an archive is and delves into what an archive can do, especially by pondering on what it means to understand one's body as an archive:

The body as an archive is an attunement, a hopeful gathering, an act of love against the foreclosures of reason. It is a way of knowing the body-self as a becoming and unbecoming thing, of scrambling time and matter, of turning toward rather than against oneself. (SINGH, 2018, p. 29)

Understanding one's body as an archive means "it is a way of thinking-feeling the body's unbounded relation to other bodies." (SINGH, 2018, p. 29) Singh highlights that bodies are not self-contained and that they allow us to go beyond the physical aspect of what archives are. Singh, then, does not single out the signs inscribed onto bodies as the only focus of archival practices. Rather, she sees that these signs - or perhaps better termed as "an infinite history of traces" - as a pathway for further enquiries into what bodies can do in affective terms.

Drawing from affect and queer theories, Singh argues that bodies are not only a case of matter, but also one of affects, especially when binary boundaries such as mind/body and reason/feeling still loom large.
This is not only a material problem for my body archive, but also an affective one. In the end, we are not bounded, contained subjects, but ones filled up with foreign feelings and vibes that linger and circulate in space, that enter us as we move through our lives. We likewise leave traces of ourselves and our own affective states (which are never really just our own) behind us when we go. (SINGH, 2018, p. 31)

Bodies, as Singh notices, are being constantly undone by the presence and traces of others - their interactions, their connections, their presences, their affects. As Singh seems to use affects, emotions and feelings interchangeably, some theorists might take issue with the lack of definitions and academic terms. This is not, however, a hindrance as her argument is that her own body as an archive allows readers to participate - and at times be mystified - by her affective journey: having a child as a disquieting experience with excrement, undergoing surgery as a negotiation between numbing pain and body, and even the purging of food as part of her feeling excluded/included in her teenager years.

What Julietta Singh's work exemplifies is that the body as an archive is a "hopeful gathering" of experiences which are not necessarily inscribed on the body but experienced in/through it. If the body as an archive is a becoming and unbecoming thing, it is not possible to neglect how bodies are undone (BUTLER, 2019) and what these undoings can offer us, especially when affects lie at the heart of the discussion. For this reason, archives become, in my perspective, an affective and productive site for questions regarding LGTBQ+ subjects as lesser existences, notably those who are not usually included under the umbrella term LGBTQ+ - non-binary people, for instance.

Taking into consideration space constraints, I am going to focus exclusively here on Danez Smith's collection Don't Call Us Dead. My interest in Smith comes from their poems which defy the so-called established lines between private and public worlds. By exploring themes such as HIV, sexuality and processes of identification, Smith manages to offer their body as an archive, particularly one of feelings. 


\section{A BODY, AN ARCHIVE}

Published in 2017, Don't Call Us Dead is Danez Smith's second poetry collection. Having already published two chapbooks and poems in different journals and sites, Danez solidified their reputation as one of the most popular contemporary poets and performers in the American scene.

In spite of being a popular name associated with movements such as Black Lives Matter, Smith has avoided being pigeonholed as a poet who writes only about politics. Their poems are explicitly political for their depiction of the experiences faced by black people while also remaining faithful to the personal perception of what it means to be an HIV-positive queer person. By exploring these grounds which are not always so easy to connect, Smith delves into what Eliane Berutti (2005) calls "the other America" or what Kathleen Stewart (1996) terms "a space on the side of the road" - both terms explicitly addressing how some populations in the USA are left aside in favour of a narrative of progress and respect. With this in mind, it is possible to approach their poems and think of them as archives that multiply the lives of those who inhabit this "other America" or the "space on the side of the road".

Stewart (1996, p. 17) encourages readers to think of culture as an "occupied, betrayed, fragmented and finally deserted place" as a "shifting space of desire immanent in lost and re-membered and imagined things." Then, it becomes easier to picture how some images of black people, especially black men, are associated with violence because of cultural practices which uses fragments to narrate such stereotypical stories. Smith addresses this issues in the poem "It Won't Be a Bullet". They challenge the stereotypical view of black men being not only the target of urban violence, but also the site of masculinity. Smith (2020, p. 64) says that "in the catalogue of ways to kill a black boy, find me / buried between the pages stuck together / with red stick. ironic, predictable, look at me." Although there are several ways in which everyone may die, it is symbolic that Smith highlights the existence of a "catalogue of ways to kill a black boy", which emphasizes the nervousness and uncertainty a black boy feels whenever out in the world.

These feelings of nervousness and uncertainty become even more critical when Smith themselves realizes how ironic and predictable the situation is because, after all, the number of black people being murdered is both alarming (soaring rates) and unalarming (people and the media do not seem to worry about it). The realisation of the lack of importance of one's life is detailed further in "It Won't Be a Bullet":

\footnotetext{
i'm not the kind of black man who dies on the news. i'm the kind who grows thinner \& thinner \& thinner until light outweighs us, \& we become it, family gathered around my barely body telling me to go toward myself. (SMITH, 2020, p. 64)
}

Smith explores how, in the "catalogue of ways", they are not going to be the target of a "bullet" - hence the title of the poem -, but the target of a slow death in which they become increasingly emaciated, thinner than the weightlessness of light itself. The image of the body becoming thin and then light itself ("we become it") works as a strong metaphor for a body which is slowly being eaten 
from the inside out by unspoken things. This body is disappearing slowly for not being able, perhaps, to express emotions or even to speak one's truth, in fear of betraying senses of masculinity. It won't be a bullet that kills this black person, but other forms of unspoken trauma which quietly disintegrate them.

While mixing different types of death and black men, Smith challenges traditional notions of masculinity. It may be argued that in their poems masculinity becomes an inventory of affects which are interrogated and undone. If "It Won't Be a Bullet" tries to negotiate melancholy, masculinity and death, "At the Down-low House Party" presents a different take on how masculinity is an affective social practice.

"Down-low" is a slang term which describes heterosexual men who engage in sexual practices with other men in secret. Employing the feelings of contradiction described by Eve Sedgwick (1990) in Epistemology of the Closet, it may be argued that binary categories such as outness/insideness or public/private are too complex to describe what these men are. Oriented by values which inform them of what a "man" is, these men Smith describes in the poem exemplify how difficult it is to establish defining lines as to how gender, desire and sexuality work - "some good brown trying to get drunk / with permission. sometime between here / \& being straight again [...]” (SMITH 2020, p. 84).

Being straight becomes, in the poem, a spatial-temporal condition in which bodies inhabit. At the same time that "being here [queer] and "being straight" blurs the limits of each space, these sides of the continuum invoke an experience which those men, who crave for the stability of straightness, allow themselves to interrupt their own normative discourses. If queer is a refusal of boundaries, this may be a possibility for the disassociation of categories of identity formation and sexual or affective practices, stressing the instability of such practices in the case of the poem.

When "some sweet / boned, glittering boi shows up [and] starts voguing \& shit", the men on the down-low experience conflicting feelings of desire and disidentification:

\author{
his sharp hips pierce our desire, make our mouths water \\ \& water \& we call him faggot meaning bravery \\ faggot meaning I often dream \\ of you, flesh damp \& confused for mine \\ faggot meaning Hail the queen! Hail the queen! \\ faggot meaning I been waited ages to dance with you. \\ (SMITH, 2020, p. 84, emphases on the original)
}

Mouths water for desire, flesh craves the touch of other men, words fail to describe or represent feelings. This experience of disidentification is, as José Esteban Muñoz (1999) describes, a complex process of desiring what is there, but desiring it differently. It is not simply a process of accepting or refusing what one desires, but one in which contradictions are part of the construction. While these men consider themselves straight, they are at a party to have sex with other men. While they call these men-loving men faggots because this is what they know of the experience of gayness (as if gayness could be a single narrative!), they also covet the flesh they see. While they do not identify themselves 
with what gayness(es) could be, they are, ironically, part of the system they refuse to acknowledge. These bodies, then, express the contradiction of an archive, especially with their refusal of being queer. What do these men's practices inform us about what queer bodies are? How can the desire these men have help us evaluate what the archive has held from us?

In a sense, what these men are doing at the party may help destabilise even concepts of queerness as they do not see themselves as queer. Their bodies serve as markers of other sexual engagements which traditional queer studies often take either for granted or for inward homophobia. However, since queerness is about destabilisation, it may be argued that other meanings may erupt from this archive. In a similar manner, Gayatri Gopinath employs different understandings of queerness in her archival practices in Unruly Visions:

The queerness of the archive $[\ldots]$ rests not only in the fact that it acts as a record of queer desires, embodiments, and affiliations that connect different temporal moments, but that it revalues that which is seen as without value: the regional, the personal, the affective, the everyday. (GOPINATH, 2018, p. 9)

Once the body is seen as an archive, "an act of love against the foreclosures of reason" as Singh (2018, p. 29) suggests, what these men do matter; even if it is something perhaps irrelevant for what is considered History with a capital $\mathrm{H}$, these practices matter. They matter because they offer an insight about how bodies have been the site of heteronormative constructions. They matter because they express how bodies and desire are not necessarily mediated by representations of fixed identities such as straight or even gay or lesbian. These representations of self-identified men-loving men and men who refuse to identify as men-loving men blurs the boundaries of a system which insists on perpetuating prejudice and LGBTQ+-phobic treatment. Were it not for a violence-ridden system, these men on the down-low would perhaps appreciate the sexual engagement without the fear of being defined by whatever sexual practices they engage in. "At the Down-low House Party", then, cannot be seen solely as a celebration of queer subjects who are free to express themselves and hypocritical men who refuse to accept their own sexuality. Rather, the poem should be seen as a mediation of overlapping processes of disidentifications in which bodies become an "archive of feelings" in the sense established by Ann Cvetkovich (2003, p. 7): “[...] an exploration of cultural texts as repositories of feelings and emotions, which are encoded not only in the content of the texts themselves but in the practices that surround their production and reception."

A body as an archive, especially one "of feelings", does not mean it is the receptacle into which affects are deposited or from which they are drawn. A body as an archive of feelings is a way of understanding the intersections in which we are located and what feelings and emotions we are drawn to. In "At the Down-low House Party" we can notice how straight bodies are affected by desire and shame simultaneously, expressing how heterosexuality works as a trauma which fabricates bodies and behaviours.

Both Julietta Singh (2018) and Ann Cvetkovich (2003) address how traumas mobilize affects and, even if these traumas are not visible scars, they manifest themselves in different affective ways. Being HIV positive, Danez Smith elaborates on how public and private domains are inextricably intertwined by exposing a self which reflects upon what it means to be a HIV-positive black person. In poems such as "Seroconversion" and "Recklessly", they play with how HIV as a trauma operates 
in lines such as "- a love story - / he came/over / \& then left / but he stayed” (SMITH, 2020, p. 104, emphasis in the original) and "in our blood / men hold each other / like they'll never let go / \& then they let go" (SMITH, 2020, p. 114). In spite of the negative affects these lines might evoke, they also present a strategy for the future by breaking the expected promise of the never-ending happiness. A love story, for instance, should not be over or even about how someone comes and goes. In this piece, Smith emphasises that even though the man went away after sex, something of him stayed, and, by following the rest of the poem, we are led to wonder what of this man has stayed - possibly the HIV status. Yet, such a gloomy perspective cannot be seen solely as negative: what Smith is doing with their poems signals that life is not over because of HIV-positive results. Instead, Smith uses their condition as a celebration of self while questioning the traditional narrative in which queer HIV-positive subjects are doomed to impending death. This reversal of meaning is only possible due to an analysis in which ugly and backward feelings (NGAI, 2005; LOVE, 2009) are productive sites.

Refusing the narrative of death as their single story, Smith manages to explore how the body works as an archive with metaphors of hauntings and ghost in "It Began Right Here":

\footnotetext{
[...] but it's still life. i will die in this bloodcell.

i'm learning to become all the space i need. i laughed today.

for a second i was unhaunted. i was the sun, not the light

from some dead star. i was before. i was negative. but i'm not that.

i am a house swollen with the dead, but still a home.

the bed where it happened is where i sleep. (SMITH, 2020, p. 130)
}

What does it mean for an archive of HIV to have a poem in which this self manages to be unhaunted for a second? What would it mean for an archive of HIV to allow itself to go beyond a narrative of gloominess and sorrow? Smith manages to interweave the private experience of HIV and the public narrative of fear of it. Recognising that there is still life and that a house "swollen with the dead" can still be a home, Smith seems to be making amends with a trauma which, for many people, should not be narrativised. The bed which they sleep on, the bed in which "it" began, becomes a symbol of bravery and not shame. It is definitely a site of conflicting feelings, but one which avoids any depletion of energy.

Smith's poems express what it means to inhabit worlds in which race, class, gender and sexuality are crucial for the understanding of bodies. While Smith's narrative in "Dear White America" and "Dinosaurs in the Hood" negotiate the aforementioned public and private experiences, especially in terms of bodies as a collective force, other poems address traumas which may be described as insidious traumas in the understanding of Laura Brown:

[...] Brown's crucial formulation of insidious trauma to describe the everyday experiences of sexism that add to the effects of more punctual traumatic experiences, such as rape, forges connections between trauma and more systemic forms of oppression. (CVETKOVICH, 2003, p. 32)

If trauma tends to be seen as a part of medicalised discourses which account for events in the public sphere which impinge on individuals, the concept of insidious trauma helps us understand, 
for instance, how racism, a systemic form of oppression, cannot be only thought of as an end of the private-public continuum. For this reason, it is interesting to think of the body as an archive which gathers all these insidious traumas which cannot be represented fully in public discourses. A body can and needs to negotiate these insidious traumas so as to be able to fully address them publicly because a refusal of feeling bad has led people to silent suffering and inability to engage. This is why negative affects, even if they are frustrating to engage with, present the challenge of how to expose them and use them effectively.

In "Dear White America”, for example, Smith mixes past and present narratives to elaborate on how colonial practices still inscribe onto black bodies negative affects. Anger may be usually seen as an affect which adheres to black subjects as in the common stereotype of the "angry black woman", yet Smith manages to voice their contempt for how white-oriented the world is through means of anger.

i am equal parts sick of your go back to Africa of i just don't see race. neither did the poplar tree. we did not build your boats (though we did leave a trail of kin to guide us home). we did not build your prisons (though we did \& we fill them too). we did not ask to be part of your America (though are we not America? her joints brittle \& dragging a ripped gown through Oakland?). i can't stand your ground. i'm sick of calling your recklessness the law. [...] i tried, white people. i tried to love you, but you spent my brother's funeral making plans for brunch, talking too loud next to his bones. you took one look at the river, plump with the body of boy after girl after sweet boi \& ask why does it always have to be about race? because you made it that way! (SMITH, 2020, p. 54, emphases on the original)

Anger becomes a productive site for self-expression, especially by mixing public and private experiences as an attempt to negotiate insidious traumas. Instead of shame or sadness, anger becomes an affect which allows for unspoken feelings to be vented. Interestingly, anger contrasts with the hope of the fantasy expressed in "Dinosaurs in the Hood" in which a black boy daydreams of his hood being part of a film with dinosaurs. Hope, in this poem, acquires the perception that a black boy, unlike stereotyped narratives, can dream of impossible things which may become attainable futures: "[...] besides, the only reason / I want to make this is for the first scene anyway: little black boy / on the bus with his toy dinosaur, his eyes wide \& endless / his dreams possible, pulsing \& right there." (SMITH, 2020, p. 60)

If we read this poem autobiographically, as many other poems here have been, we may clearly notice that Smith attempts to instill confidence into this little black boy so that when he grows up, he may decide what his dreams are - even if his dreams seem unlikely to be fulfilled. This blurring of autobiographical perspectives and intersectionality advances a productive realm in which Smith's poems make it possible for lesser existences, as discussed previously, to become real. By giving these existences voices and space, Smith interrogates the very fiber of their body: how can these experiences and these traumas be made real without tethering them to essentialist narratives? The answer is their offering of the body as an archive in which feelings and emotions become traces of existences previously denied voices.

A body as an archive is, thus, a complex negotiation between feelings and the world, a negotiation in which new meanings can be lifted from archival practices that challenge stereotypical views. Excavating what is personal, public and political in an intersectional perspective, Smith avoids representing black subjects as fixed identities while operating with personal traumas as well. In a way, it is possible to argue that they use their body as an archive to make room for voices such as theirs in a scene too concerned with stable notions of identity and very little attention to systemic oppression. 


\section{CONCLUSION}

A body in Don't Call Us Dead is not only a site for pain and melancholy, it is also an archive in which traumas can be expressed and negotiated through other feelings. A body in this collection of poems is an expression of what failure looks like - being unable to dream, being sexually dissident, not conforming with societal values, being HIV positive, being queer -, yet failure here is understood in the words of Jack Halberstam (2020): not being successful according to heteronormative values is a painful process, but also one filled with joys of creation and chances to experiment. Failures may affect us negatively, especially in a world full of difficulties and challenges, but failing can help undo the toxic positivity which surrounds and bounds us.

If archives were previously read in search of stories which would normalise some narratives, what Don't Call Us Dead offer is a possibility in which gender, sexuality and desire are unapologetically thematised as a crucial reading of the body. In this sense, the body becomes an archive in which new meanings of previously fixed notions arise and allow for voices to not only speak, but also to be heard. Refusing to solely rely on either the personal or the public, Danez Smith somehow stresses that an archival practice which focuses on healing stories is likely to fail because healing comes from facing what terrifies one the most: "let him enter the lion's cage / \& find a field of lilacs / let this be the healing / \& if not let it be." (SMITH, 2020, p. 192)

\section{REFERENCES}

AHMED, Sara. The Promise of Happiness. Durham: Duke University Press, 2010.

BERUTTI, Eliane. Focalizando a "outra América": questões de identidade e fobia. In: HENRIQUES, Ana Lucia de Souza (Org.). Literatura e Comparativismo. Rio de Janeiro: EdUERJ, 2005. p.37-46.

BUTLER, Judith, Bodies that Matter: On the discursive limits of 'sex'. New York and London: Routledge, 1993.

BUTLER, Judith. Vida Precária: Os poderes do luto e da violência. Translated by Andreas Lieber. Belo Horizonte: Editora Autêntica, 2019.

CVETKOVICH, Ann. An Archive of Feelings: Trauma, sexuality, and lesbian public cultures. Durham \& London: Duke University Press, 2003.

FRECCERO, Carla. Queer Spectrality: haunting the past. In: HAGGERTY, George; McGARRY, Molly (Org.). A Companion to Lesbian, Gay, Bisexual, Transgender, and Queer Studies. Malden \& Oxford: Blackwell Publishing, 2007.p. 194-213.

GOPINATH, Gayatri. Unruly Visions: The aesthetic practices of queer diaspora. Durham \& London: Duke University Press, 2018.

HALBERSTAM, Jack. A Arte Queer do Fracasso. Translated by Bhuvi Libanio. Recife: Cepe, 2020.

HEMMINGS, Clare. "Invoking Affect: Cultural theory and the ontological turn”. Cultural Studies, Abingdonon-Thames, v. 19, n. 5, p-548-567, 2005.

LAPOUJADE, David. As Existências Mínimas. Translated by Hortencia Santos Lencastre. São Paulo: N-1 Edições, 2017. 
LOVE, Heather. Feeling Backward: Loss and the politics of queer history. Cambridge \& London: Harvard University Press, 2009.

MUÑOZ, José Esteban. Disidentifications: Queers of color and the performance of politics. Minneapolis \& London: University of Minnesota Press, 1999.

NASH, Jennifer C. Black Feminism Reimagined: After Intersectionality. Durham \& London: Duke University Press, 2019.

NGAI, Sianne. Ugly Feelings. Boston: Harvard University Press, 2005.

PEDROSA, Celia. (Org.). Indicionário do Contemporâneo. Belo Horizonte: Editora UFMG, 2018.

SEDGWICK, Eve Kosofsky. Epistemology of the Closet. Berkeley and Los Angeles: University of California Press, 1990.

SEDGWICK, Eve Kosofsky. Touching Feeling: Affect, pedagogy, performativity. Durham \& London: Duke University Press, 2003.

SINGH, Julietta. No Archive Will Restore You. Goleta: Punctum Books, 2018.

SMITH, Danez. Não Digam que Estamos Mortos (Bilingual Edition). Translated by André Capilé. Rio de Janeiro: Bazar do Tempo, 2020.

STEWART, Kathleen. A Space on the Side of the Road: Cultural poetics in an "other" America. Princeton: Princeton University Press, 1996. 